\title{
Sistem Pendukung Keputusan Pemilihan Paket Pernikahan Dengan Metode Saw Berbasis Web
}

\author{
Irvan Sulistiya Putra ${ }^{1}$, FX. Ferdinandus ${ }^{2}$, Muhaji Bayu ${ }^{3}$

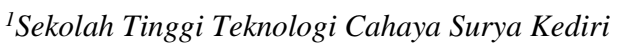 \\ ${ }^{2}$ Sekolah Tinggi Teknik Surabaya \\ ${ }_{3}^{3}$ Sekolah Tinggi Teknologi Cahaya Surya Kediri \\ E-mail:irvan.sulistiyaphotography@gmail.com,ferdi@stts.edu,muhajibayu_stt@cahayasurya.ac.id
}

\begin{abstract}
Abstrak
Pernikahan merupakan acara sakral dimana dua orang saling mengikat janji dalam ikatan perkawinan yang sah. Mempersiapkan momen pesta pernikahan yang berkesan merupakan hal yang tidak mudah bagi calon pengantin, sehingga calon pengantin memerlukan jasa Wedding Organizer. Akan tetapi, berbagai paket pernikahan yang disediakan oleh Wedding Organizer tidak jarang menyulitkan pelanggan untuk memilih. Dari analisa tersebut, sebuah aplikasi pendukung keputusan sangat dibutuhkan guna membantu Wedding Organizer mengelola paket pernikahan dan membantu pelanggan dalam memilih paket yang sesuai dengan buget. Simple Additive Weighting menjadi metode yang dipakai pada sistem ini. PHP dan $\mathrm{Html}$ sebagai bahasa pemrograman, server Laragon dengan $M y S Q L$ sebagai databasenya. Penelitian dilakukan pada Sulistiya Wedding Organizer dengan menggunakan wawancara dan observasi sebagai metode untuk mengumpulkan data. Hasil dari sistem ini nantinya dapat menampilkan alternatif paket pernikahan berdasarkan peringkat.
\end{abstract}

Kata kunci : HTML, MySQL, SPK, Simple Additive Weighting, Paket Pernikahan, PHP.

\section{Pendahuluan}

\subsection{Latar Belakang Masalah}

Pernikahan merupakan acara yang sakral dimana dua orang saling mengikat janji dihadapan penghulu, kedua orang tua dan saksi untuk disahkan menurut hukum agama, hukum negara dan hukum adat. Pernikahan juga dapat diartikan sebagai puncak acara setelah kedua calon pengantin melaksanakan lamaran. Pernikahan yang berkesan selalu diinginkan setiap calon pengantin dan sanak keluarga terutama saat pesta pernikahan dilangsungkan. Namun, calon pengantin sering bimbang dalam mempersiapkan segalanya, berkaitan dengan acara yang akan diselenggarakan. Seiring berkembangnya waktu, penyedia jasa atau yang biasa disebut wedding organizer menjadi salah satu dari beberapa alternatif dalam mempersiapkan acara pernikahan.

Perkembangan era digital dewasa ini tidak bisa dipungkiri, apalagi dengan banyaknya portofolio wedding organizer yang bisa kita temui pada saat membuka media sosial seperti facebook dan juga instagram. Mereka mempunyai standar yang berbeda, khususnya perihal paket harga untuk setiap acara. Tidak jarang, harga yang ditawarkan tidak sesuai dengan buget. Penelitian dilakukan disalah satu wedding organizer yang ada di Kediri. Sulistiya Wedding Organizer. Hasil dari penelitian serta pembuatan sistem pendukung keputusan dalam memilih paket pernikahan ini sebagai solusi mempermudah masyarakat dalam hal ini calon pengantin dan juga mempermudah Sulistiya Wedding Organizer dalam memberikan pelayanan sesuai dengan kriteria yang telah diinginkan. 


\subsection{Tujuan Penelitian}

Tujuan yang dapat dicapai dalam pembuatan program aplikasi pada Tugas Akhir yang sedang di kerjakan ini, yaitu: Membuat sebuah sistem pendukung keputusan pemilihan paket pernikahan dengan metode SAW berbasis web sesuai dengan kriteria yang sudah ditentukan.

\subsection{Pembatasan Masalah}

Peneliti membatasi masalah-masalah yang dibahas pada Tugas Akhir ini ke dalam ruang lingkup : Kriteria yang diuji meliputi jarak tempuh, lokasi acara, tenda, dekorasi, rias pengantin, sound system, dokumentasi, katering, hiburan, jumlah tamu. Metode yang digunakan untuk aplikasi ini yaitu Simple Additive Weighting. Aplikasi ini dirancang menggunakan bahasa pemrogran PHP, Html, Laragon dengan MySQL sebagai databasenya. Penelitian hanya dilakukan pada Sulistiya Wedding Organizer.

\section{Landasan Teori}

\subsection{Pengertian Pernikahan}

Pernikahan adalah hubungan antara laki-laki dengan perempuan yang diakui secara sah menurut hukum agama, hukum negara, dan hukum adat, dan menetapkan peran antara pasangan (suami-istri).

\subsection{Pengertian Wedding Organizer}

Secara umum, wedding organizer merupakan jasa yang memberikan penawaran layanan dan informasi dalam perencanaan pelaksaan rangkaian acara dalam suatu pernikahan.

\subsection{Pengertian Sistem Pendukung Keputusan}

Menurut Fitriani(2012), sistem pendukung keputusan diarancang untuk mendukung seluruh tahap pengambilan keputusan mulai dari mengidentifikasikan masalah, memilih data yang relevan, dan menentukan pendekatan yang digunakan dalam proses pengambilan keputusan sampai mengevaluasi pemilihan alternatof-alternatif yang ada.

\subsection{Simple Additive Weighting}

Metode SAW sering juga dikenal dengan istilah metode penjumlahan terbobot. Konsep dasar metode SAW adalah penjumlahan terbobot dari rating nilai kinerja pada setiap alternatif pada semua atribut. Metode SAW membutuhkan proses normalisasi matriks keputusan (x) ke suatu skala yang diperbadingkan dengan semua rating alternatif yang ada. Berikut rumusnya :

$$
r_{i j}=\left\{\begin{array}{c}
\frac{x_{i j}}{M a x_{i} x_{i j}} j i k a \mathrm{j} \text { adalah atribut keuntungan (benefit) } \\
\frac{M_{i} x_{i j}}{x_{i j}} j i k a \mathrm{j} \text { adalah atribut biaya (cost) }
\end{array}\right.
$$

Dimana :

$r_{i} \quad=$ rating kinerja ternormalisasi dari alternatif $\mathrm{Ai}(\mathrm{i}=, 2, . ., \mathrm{m}$ dan $\mathrm{j}=1,2, \ldots, \mathrm{n})$

$M \quad i$ = nilai maksimum dari setiap baris dan kolom.

$M_{i} \quad=$ nilai minimum dari setiap baris dan kolom.

$x_{i} \quad=$ baris dan kolom dari matriks.

Benefit $=$ jika nilai terbesar adalah yang terbaik.

Cost $=$ jika nilai terkecil adalah yang terbaik. 
Dimana rij adalah rating kinerja ternormalisasi dari alternatif $\mathrm{Ai}$ pada atribut $\mathrm{Cj} ; \mathrm{i}=1,2, \ldots, \mathrm{m}$ dan $\mathrm{j}=1,2, \ldots, \mathrm{n}$. Nilai preferensi untuk setiap alternative (Vi) diberikan sebagai :

$$
V_{i}=\sum_{j=1}^{n} w_{j} r_{i}
$$

Dimana:

$V_{i} \quad=$ Nilai akhir dari alternatif

$w_{j} \quad=$ Bobot yang telah ditentukan

$r_{i} \quad=$ Normalisasi matriks.

Nilai Vi yang lebih besar mengindikasikan bahwa aternatif Ai lebih terpilih (Kusumadewi, Harjoko, dan Wardoyo. 2006).

\subsection{Pengertian Laragon}

Laragon ialah perangkat lunak bebas yang di dalamnya terdapat banyak sistem operasi sebagai localhost atau server mandiri. Laragon menyediakan banyak layanan, peralatan, dan fitur yang terdiri dari Apache, PHP Server, PHPMyAdmin, MySQL, Memchaced, Redis, Composer, Xdebug, Cmder dan Laravel.

\subsection{Pengertian Web}

Web terbagi menjadi dua jenis, yaitu web dinamis dan statis, web statik ialah web yang isinya tidak bisa berubah, maksudnya isi dari dokumen tersebut tidak dapat diubah dengan cepat, dikarenakan teknologi yang dipakai membuat dokumen web tidak memungkinkan untuk melakukan perubahan isi. Teknologi yang dipakai web statis ialah jenis CSS seperti HTML, Contoh situs web statis diantaranya adalah web profile sebuah perusahaan yang lebih dominan menggunakan HTML.

Web Dinamis ialah web yang kontennya dapat berubah-ubah setiap saat. dalam membuat web dinamis perlu beberapa komponen yaitu HTML, Javascript, CSS dan PHP, basis data seperti $M y S Q L$ diperlukan untuk menyimpan data. Contoh situs web dinamis adalah situs web berita, situs web penjualan.

\subsection{Pengertian HTML}

Hypertext Markup Language ialah suatu bahasa markah yang dipakai dalam membuat suatu tampilan web, berbagai informasi didalam sebuah penjelajahan Internet dan format hiperteks sederhana, ditulis dengan berkas ASCII agar bisa menghasilkan tampilan yang terintegerasi. berkas yang dimuat dalam piranti lunak pengolahan data dan disimpan kedalam sebuah format ASCII agar bisa dapat menjadi halaman sebuah web dengan perintah HTML. Berawal dari bahasa yang banyak dipakai sebelumnya didalam dunia percetakan dan juga dunia penerbitan yang biasa disebut dengan Standard Generalized Markup Language atau SGML, HTML menjadi sebuah standar yang dipakai secara luas dalam menampilkan halaman web.

\subsection{Pengertian PHP}

PHP sendiri merupakan sebuah bahasa pemrograman yang dipakai untuk membuat coding website dinamis yang memungkinkan kita untuk melakukan update pada website setiap saat. Berbeda halnya dengan markah HTML yang memuat source kode yang ditampilkan didalam website, sedangkan source code PHP sendiri tidak di tampilkan didalam halaman suatu website dikarenakan PHP diproses dan di olah didalam sebuah server, selain itu PHP juga bersifat server side script yang mampu dijalankan di beberapa system operasi seperti linux, windows, dll. Dalam database PHP memiliki kedinamisan yang bisa dihubungkan langsung dengan MySQL, Oracle. Namun untuk pemrograman websitenya sendiri yang digunakan adalah MySQL. PHP 
sampai saat ini telah mengalami kemajuan yang begitu pesat dan. untuk mengawali kode dalam PHP digunakan code <? Dan di tutup dengan code ?>

\subsection{Pengertian Data Flow Diagram}

Menurut (Kristanto, 2008) Data Flow Diagram (DFD) adalah model logika data atau proses yang dibuat untuk menggambarkan darimana asal data, kemana tujuan data yang keluar dari sistem, dimana data disimpan, proses apa yang dihasilkan data tersebut dan interaksi antara data yang tersimpan dan proses yang dikenakan pada data tersebut.

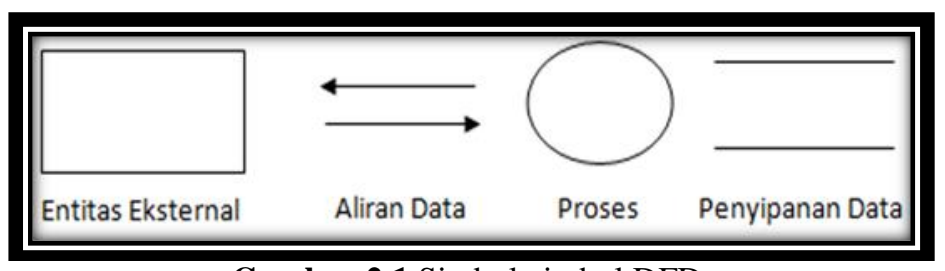

Gambar 2.1 Simbol-simbol DFD

\subsection{Pengertian Flowchart}

Definisi flowchart atau diagram alur menurut Sugiono (2005) adalah simbol - simbol yang digunakan untuk menggambarkan urutan proses atau instruksi - instruksi yang terjadi di dalam suatu program komputer secara sistematis dan logis.

\subsection{Pengertian Entity Relationship Diagram}

Menurut Sutanta(2014), "Entity Relationship Diagram (ERD) merupakan suatu model data yang dikembangkan berdasarkan objek." Entity Relationship Diagram (ERD) digunakan untuk menjelaskan hubungan antar data dalam basis data kepada pengguna secara logis. Entity Relationship Diagram (ERD) didasarkan pada suatu persepsi bahwa real world terdiri atas obyek-obyek dasar tersebut. Penggunaan Entity Relationship Diagram (ERD) relatif mudah dipahami, bahkan oleh para pengguna yang awam. Bagi perancang atau analis sistem, Entity Relationship Diagram (ERD) berguna untuk memodelkan sistem yang nantinya, basis data akan di kembangkan. Model ini juga membantu perancang atau analis sistem pada saat melakukan analis dan perancangan basis data karena model ini dapat menunjukkan macam data yang dibutuhkan dan kerelasian antar data didalamnya.

Menurut Sutanta(2011)Komponen Entity Relationship Diagram (ERD):

1. Entitas Entitas merupakan suatu objek yang dapat dibedakan dari lainnya yang dapat diwujudkan dalam basis data. Objek dasar dapat berupa orang, benda, atau hal yang keterangannya perlu disimpan didalam basis data. Untuk menggambarkan sebuah entitas digunakan aturan sebagai berikut:

a. Entitas dinyatakan dengan simbol persegi panjang.

b. Nama entitas dituliskan didalam simbol persegi panjang.

c. Nama entitas berupa kata benda, tunggal.

d. Nama entitas sedapat mungkin menggunakan nama yang mudah dipahami dan dapat menyatakan maknanya dengan jelas.

2. Atribut Atribut merupakan keterangan-keterangan yang terkait pada sebuah entitas yang perlu disimpan dalam basis data. Atribut berfungsi sebagai penjelas pada sebuah entitas. Untuk menggambarkan atribut digunakan aturan sebagai berikut:

a. Atribut digambarkan dengan simbol ellips.

b. Nama atribut dituliskan didalam simbol ellips.

c. Nama atribut merupakan kata benda, tunggal. 
d. Nama atribut sedapat mungkin menggunakan nama yang mudah dipahami dan dapat menyatakan maknanya dengan jelas.

3. Relasi Relasi merupakan hubungan antara sejumlah entitas yang berasal dari himpunan entitas yang berbeda. Aturan penggambaran relasi adalah sebagai berikut :

a. Relasi dinyatakan dengan simbol belah ketupat.

b. Nama relasi dituliskan didalam simbol belah ketupat.

c. Nama relasi berupa kata kerja aktif.

d. Nama relasi sedapat mungkin menggunakan nama yang mudah dipahami dan dapat menyatakan maknanya dengan jelas.

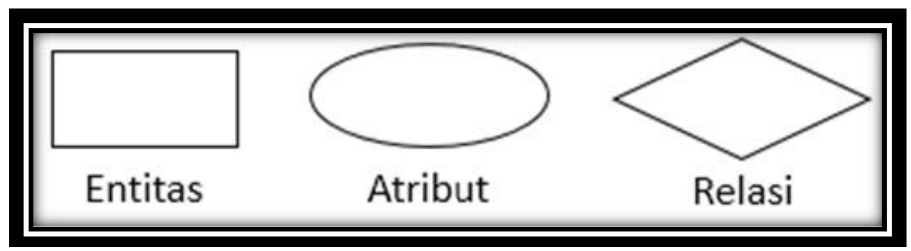

Gambar 2.2 Simbol-simbol ERD

\section{Perancangan Sistem}

\subsection{Rancangan Sistem}

Sistem pendukung keputusan pemilihan paket pernikahan ini dapat digambarkan dalam bentuk berupa context dia- gram, data flow diagram, flowchart dan entitiy relationship diagram yang dapat dijelaskan pada subbab ini.

\subsection{Analisis Kebutuhan Sistem}

Definisi kebutuhan sistem adalah faktor-faktor yang diperlukan oleh sistem dan diperlukan untuk perancangan pe- rangkat lunak tersebut sesuai dengan maksud dan tujuan pembuatannya. Perancangan sistem pendukung keputusan pemilihan paket pernikahan ini membutuhkan perangkat lain sebagai pendukung agar pembuatan sistem pendukung keputusan pemilihan paket pernikahan ini dapat berjalan sesuai fungsi dan tujuannya.

\subsubsection{Analisis Kebutuhan Fungsional}

Analisis kebutuhan fungsional adalah jenis kebutuhan yang berisikan prosesproses apa saja yang diberikan oleh sistem informasi. Sistem ini dapat digunakan oleh pengguna yaitu admin dan client, dimana admin dan client memiliki hak akses yang berbeda didalam sistem tersebut.

Analisis kebutuhan fungsional terbentuk dan dapat dikategorikan sebagai berikut :

1. Kebutuhan admin

a. User admin dapat melakukan input data paket pernikahan..

b. User admin dapat melakukan input data client.

2. Kebutuhan client

a. Melakukan login setelah menerima password dari admin

b. Melakukan pemilihan paket, melakukan perhitungan paket, melihat hasil perhitungan paket, dan melakukan order.

Untuk memenuhi kebutuhan fungsional sistem pemesanan kost dan dokumen diatas, maka diperlukan input ke sistem. 
Masukan ke sistem terdiri dari :

a. Input data user

b. Input data kriteria

c. Input data sub kriteria

d. Input data alternatif

e. Input data pemesanan paket pernikahan

Proses ke sistem terdiri dari :

a. Proses perhitungan simple additive weighting

Keluaran atau output ke sistem terdiri dari :

a. Laporan hasil perhitungan

b. Laporan rekomendasi paket

c. Laporan pemesanan paket pernikahan

\subsubsection{Analisis Kebutuhan Non-Fungsional}

Analisis kebutuhan non fungsional adalah kebutuhan yang tidak secara langsung terkait dengan fitur tertentu didalam sistem. Kebutuhan perangkat keras dalam membangun aplikasi ini dibagi menjadi analisis perangkat keras/hardware, dan analisis perangkat lunak/software.

\subsubsection{Analisis Perangkat keras / hardware}

Untuk sistem perangkat keras dalam hal ini menggunakan sebuah notebook dengan spesifikasi sebagai berikut :

1. Processor Intel Core i3-6006U .

2. RAM 4GB.

3. Harddisk $500 \mathrm{~GB}$..

4. Perangkat standart input dan output.

\subsubsection{Analisis Perangkat Lunak/software}

Adapun perangkat lunak yang digunakan dalam membangun aplikasi ini adalah sebagai berikut :

1. Sistem Operasi Microsoft Windows 10 64-bit.

2. Laragon.

3. Sublime

4. Web Browser

\subsection{Context Diagram}

Langkah awal dalam pembuatan sistem informas yaitu membuat context diagram yang merupakan top level yang nantinya akan digunakan pada sistem pendukung keputusan pemilhan paket pernikahan. Pada context diagram ini hanya terdapat satu proses, tidak boleh ada store atau penyimpanan dalam context diagram. Berikut gambaran sistem dengan context diagram.

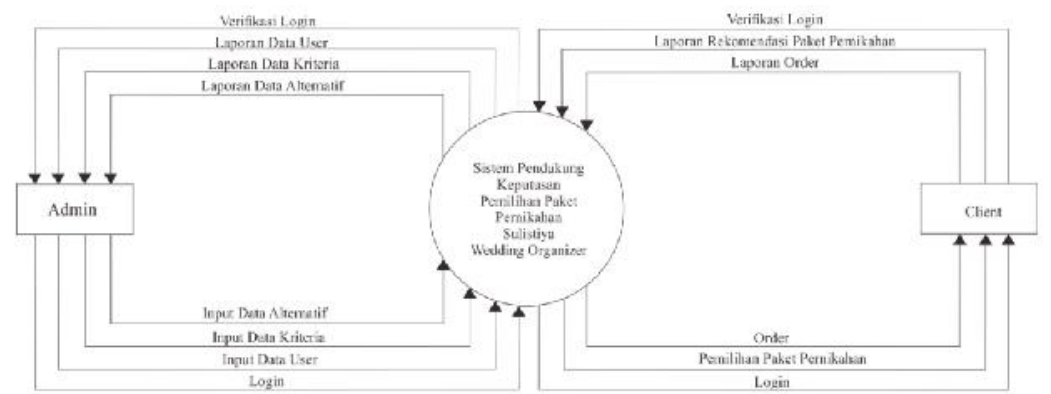

Gambar 3.1. Context Diagram Sistem Pendukung Keputusan Pemilhan Paket Pernikahan 


\subsection{Data Flow Diagram}

Data Flow Diagram (DFD) merupakan pengembangan dari context diagram. Diagram ini merupakan gambaran seca ra khusus dengan penjelasan secara detail didalam menganalisa sistem pendukung keputusan pemilhan paket pernikahan seperti dibawah ini :

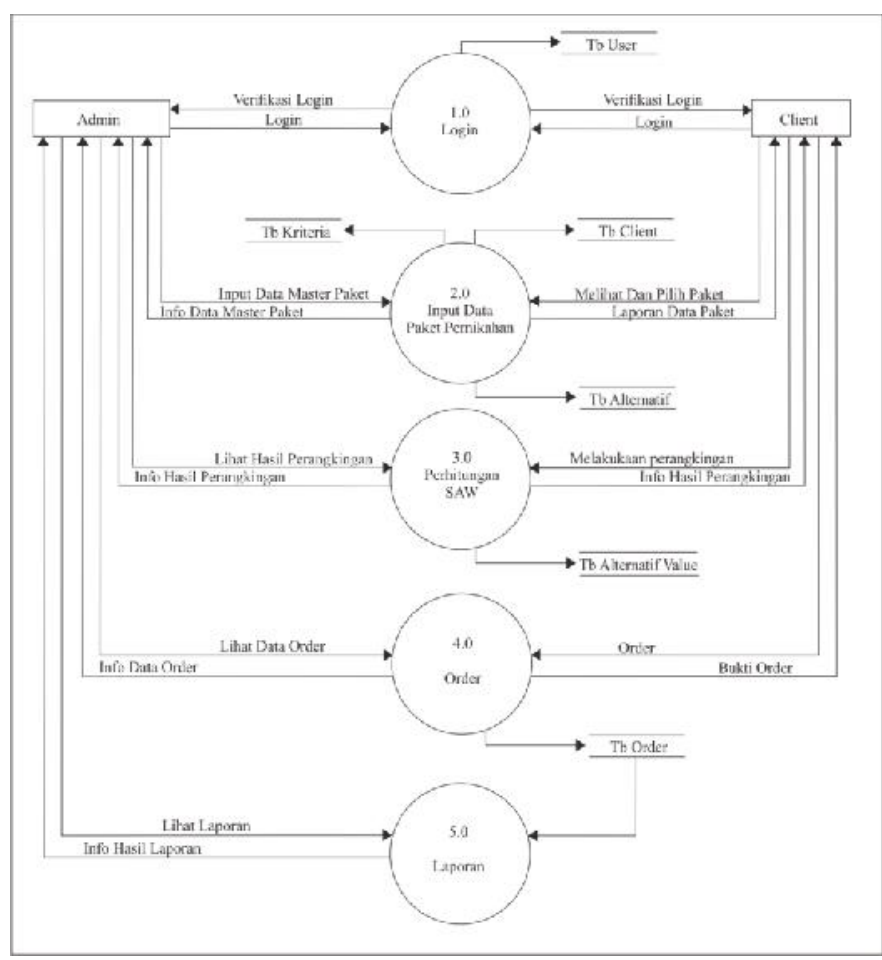

Gambar 3.2. Data Flow Sistem Pendukung Keputusan Pemilhan Paket Pernikahan

\subsection{Flowchart}

Alur sistem yang berjalan pada sistem pendukung keputusab pemilihan paket pernikahan pada Sulistiya Wedding Organizer sebagai berikut :

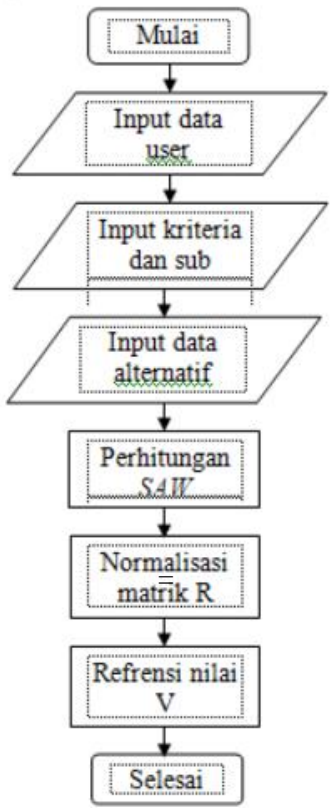

Gambar 3.3. Data Flow Sistem Pendukung Keputusan Pemilhan Paket Pernikahan 


\subsection{Entity Relationship Diagram}

Entity Relationships Diagram atau ERD merupakan diagram relasi antar tabel. Pada proses ini elemen-elemen data dikelompokkan menjadi satu file database beserta entitas dan hubungannya. ERD berisi data tabel yang telah dikelompokkan didalam database MySQL Phpmyadmin. ERD dapat dilihat langkah langkah antar relasi yang memiliki hubungan antara satu tabel dengan tabel lainnya.

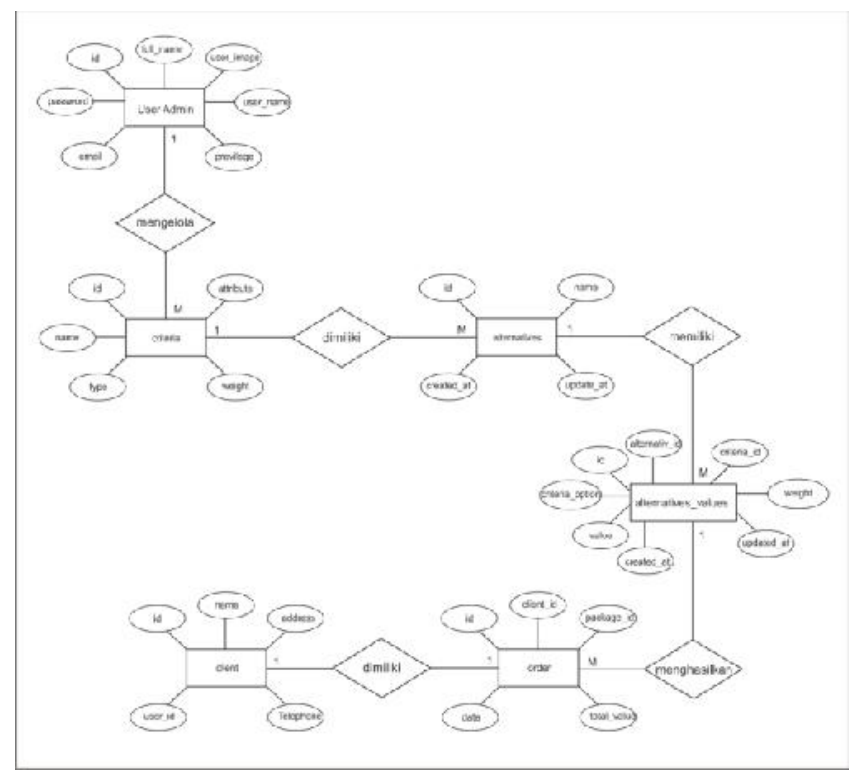

Gambar 3.4. Alur ERD

\subsection{Rancangan Basis Data}

Perancangan basis data dilakukan untuk menentukan bagaimana relasi dan struktur tabel yang akan dibuat pada pengembangan sistem.

\subsubsection{Tabel Data Admin}

Tabel 3.1 Tabel Data Admin

\begin{tabular}{|l|l|l|l|l|}
\hline No & \multicolumn{1}{|c|}{ Nama } & \multicolumn{1}{c|}{ Tipe } & \multicolumn{1}{c|}{ Panjang } & Keterangan \\
\hline 1. & id & int & 10 & Primary key \\
\hline 2 & username & varchar & 10 & \\
\hline 3 & password & varchar & 25 & \\
\hline 4 & name & varchar & 25 & \\
\hline 5 & email & varchar & 25 & \\
\hline 6 & previllege & char & 25 & \\
\hline 7 & created_at & timestamp & & \\
\hline 8 & update_at & timestamp & & \\
\hline
\end{tabular}

\subsubsection{Tabel Data Client}

Tabel 3.2 Tabel Data Client

\begin{tabular}{|c|c|c|c|c|}
\hline No & Nama & Tipe & Panjang & Keterangan \\
\hline 1 & id & int & 10 & Primary key \\
\hline 2 & name & varchar & 25 & \\
\hline 3 & address & varchar & 25 & \\
\hline 4 & telp & $\operatorname{chs} a r$ & 25 & \\
\hline 5 & user id & int & 25 & \\
\hline 6 & created at & timestanp & & \\
\hline 7 & update_at & timestamp & & \\
\hline
\end{tabular}




\subsubsection{Tabel Data Kriteria}

Tabel 3.3 Tabel Data Kriteria

\begin{tabular}{|l|l|l|l|l|}
\hline No & Nama & Tipe & Panjang & Keterangan \\
\hline 1. & id & int & 10 & Primarykey \\
\hline 2 & name & varchar & 25 & \\
\hline 3 & description & varchar & 25 & \\
\hline 4 & attribute & varchar & 25 & \\
\hline 5 & type & varchar & 25 & \\
\hline 6 & weight & decimal & 7,2 & \\
\hline 7 & created at & timestamp & & \\
\hline 8 & update_at & timestamp & & \\
\hline
\end{tabular}

\subsubsection{Tabel Data Alternativ Kriteria}

Tabel 3.4 Tabel Data Alternative Kriteria

\begin{tabular}{|l|l|l|l|l|}
\hline No & \multicolumn{1}{|c|}{ Nama } & \multicolumn{1}{c|}{ Tipe } & \multicolumn{1}{c|}{ Panjang } & Keterangan \\
\hline 1 & id & int & 10 & Primary key \\
\hline 2 & criteria id & int & 25 & \\
\hline 3 & name & varchar & 25 & \\
\hline 4 & value & decimai & 7,2 & \\
\hline 5 & Price & varchar & 25 & \\
\hline 7 & created at & timestamp & & \\
\hline 8 & update at & timestamp & & \\
\hline
\end{tabular}

\subsubsection{Tabel Subktiteria}

Tabel 3.5 Tabel Data Subkriteria

\begin{tabular}{|l|l|l|l|l|}
\hline No & \multicolumn{1}{|c|}{ Nama } & \multicolumn{1}{c|}{ Tipe } & \multicolumn{1}{c|}{ Panjang } & Keterangan \\
\hline 1 & id & int & 10 & Primary key \\
\hline 2 & criteria id & int & 25 & \\
\hline 3 & name & varchar & 25 & \\
\hline 4 & value & decimal & 7,2 & \\
\hline 5 & Price & varchar & 25 & \\
\hline 7 & created at & timestamp & & \\
\hline 8 & update at & timestamp & & \\
\hline
\end{tabular}

\subsubsection{Tabel Data Order}

Tabel 3.6 Tabel Data Order

\begin{tabular}{|l|l|l|l|l|}
\hline No & \multicolumn{1}{|c|}{ Nama } & \multicolumn{1}{c|}{ Tipe } & \multicolumn{1}{c|}{ Panjang } & Keterangan \\
\hline 1 & id & int & 10 & Primary key \\
\hline 2 & client_id & int & 10 & \\
\hline 3 & package_id & int & 10 & \\
\hline 4 & total_value & char & 25 & \\
\hline 5 & Address & varchar & 50 & \\
\hline 6 & created_at & timestamp & & \\
\hline 7 & update_at & timestamp & & \\
\hline
\end{tabular}

\subsubsection{Tabel Data Order Items}

Tabel 3.7 Tabel Data Order Items

\begin{tabular}{|l|l|l|l|l|}
\hline No & \multicolumn{1}{|c|}{ Nama } & \multicolumn{1}{c|}{ Tipe } & \multicolumn{1}{c|}{ Panjang } & Keterangan \\
\hline 1 & id & int & 10 & Primary key \\
\hline 2 & order id & int & 10 & \\
\hline 3 & criteria id & int & 10 & \\
\hline 4 & telp & char & 25 & \\
\hline 5 & price & int & 17,2 & \\
\hline 6 & created at & timestamp & & \\
\hline 7 & update at & timestamp & & \\
\hline
\end{tabular}




\section{Implementasi Dan Pembahasan}

Kegiatan setelah melakukan perancangan sistem adalah kegiatan implementasi dan pembahasan merupakan usaha untuk sistem yang dirancang efisien dimana yang nantinya apakah sistem baru yang diusulkan relevan atau tidak.

\subsection{Implementasi Aplikasi}

Pada implementasi aplikasi ini yaitu hasil gambar dari perancangan interface dan source code yang digunakan pada pembuatan aplikasi. Implementasi pada aplikasi menggunakan website.

\subsubsection{Implementasi Antarmuka Web Login}

Halaman masuk atau login merupakan langkah awal untuk menjalankan sistem. Pengguna tidak bisa menjalankan aplikasi jika tidak memiliki username dan password aplikasi. Pengguna yang dimaksud adalah admin yang bertugas mengelola data yang terdapat pada sistem web. Implementasi antarmuka web login ditunjukkan pada gambar dibawah ini

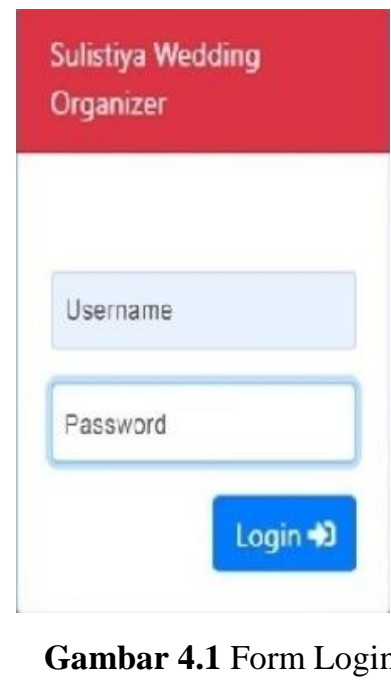

\subsubsection{Implementasi Antarmuka Web Pada Admin}

Halaman utama atau home merupakan langkah awal untuk menjalankan sistem. User bisa melihat tampilan home pada aplikasi. Pengguna yang dimaksud adalah admin dan client yang terdapat pada sistem web. Implementasi antarmuka web home ditunjukkan pada gambar dibawah ini

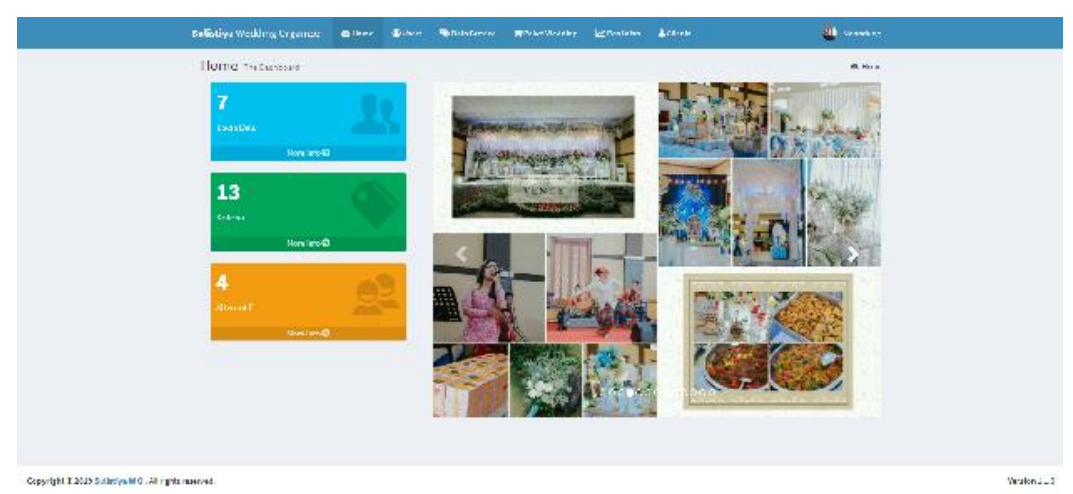

Gambar 4.2 Halaman Admin 


\subsubsection{Implementasi Antarmuka Users}

Halaman users merupakan langkah awal untuk melihat detail dari admin maupun client yang ditambahkan. Admin dapat melihat tampilan pada aplikasi. Implementasi antarmuka web detail users ditunjukkan pada gambar dibawah ini :

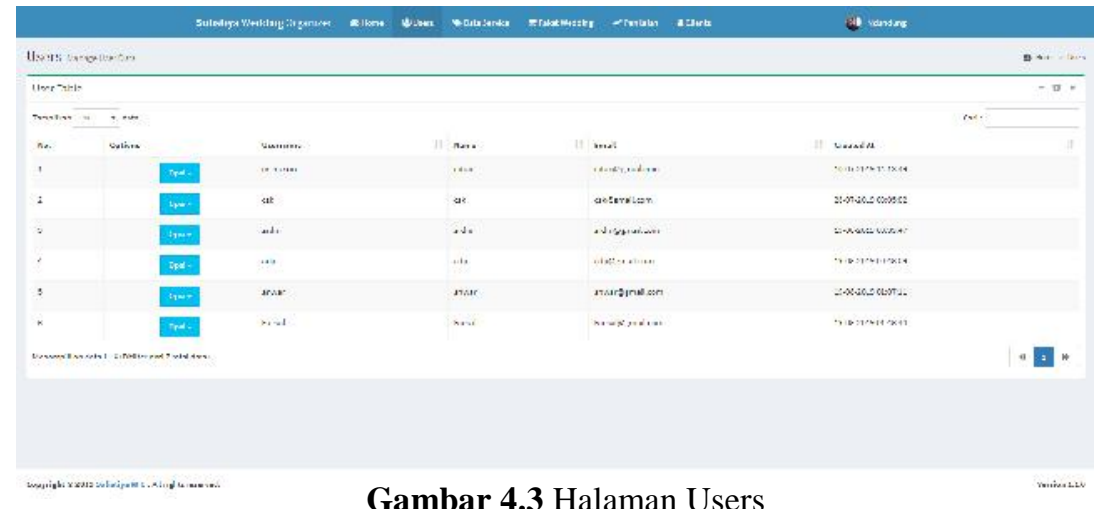

Gambar 4.3 Halaman Users

\subsubsection{Implementasi Antarmuka Data Servis}

Halaman data servis merupakan langkah untuk melihat kriteria pelayanan yang diberikan. Implementasi antarmuka web data servis ditunjukkan pada gambar dibawah ini

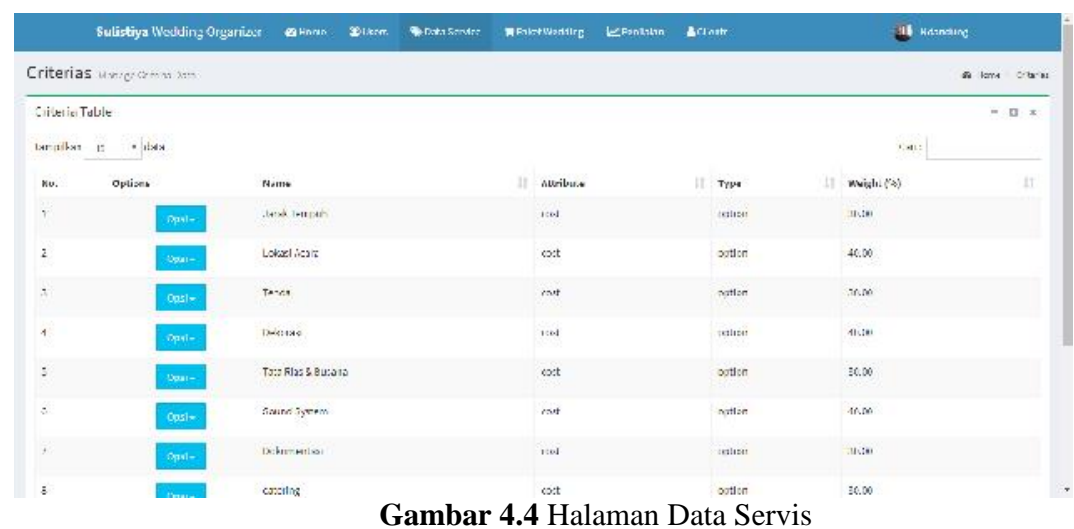

\subsubsection{Implementasi Antarmuka Paket Wedding}

Halaman paket wedding merupakan langkah untuk melihat paket alternative yang disediakan. Implementasi antarmuka web paket wedding ditunjukkan pada gambar dibawah ini

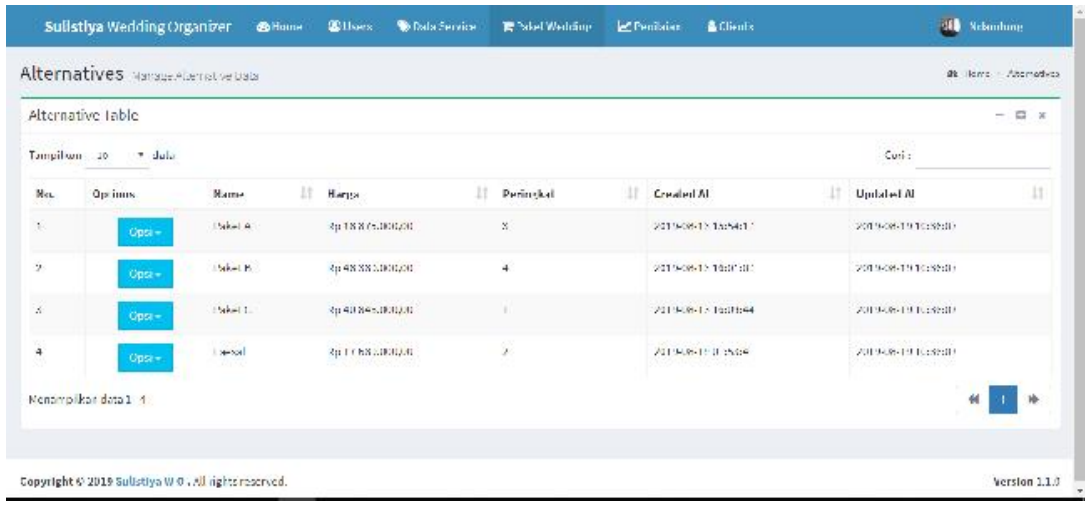

Gambar 4.5 Halaman Pemilihan Paket 


\subsubsection{Implementasi Antarmuka Subkriteria Paket Wedding}

Halaman subkriteria paket wedding merupakan langkah untuk melihat detail dari paket tersebut. Implementasi antarmuka web data kamar kost ditunjukkan pada gambar dibawah ini

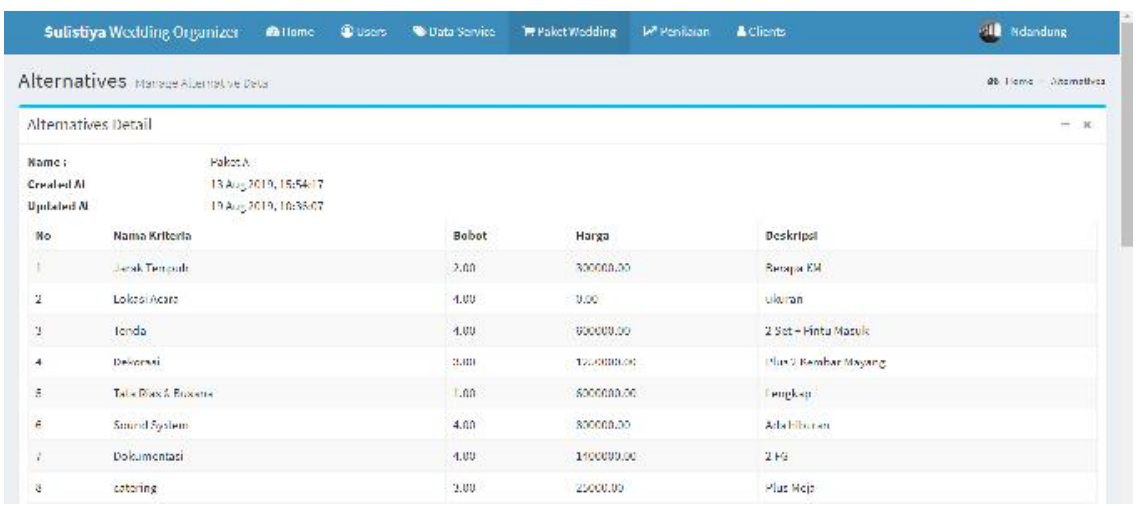

Gambar 4.6 Halaman Subkriteria Paket

\subsubsection{Implementasi Antarmuka Penilaian}

Halaman data penilaian merupakan halaman penilaian paket. Dalam penilaian ini nantinya akan menampilkan hasil perhitungan dan juga rangking dari paket yang ada. Implementasi antarmuka web data kamar kost ditunjukkan pada gambar dibawah ini

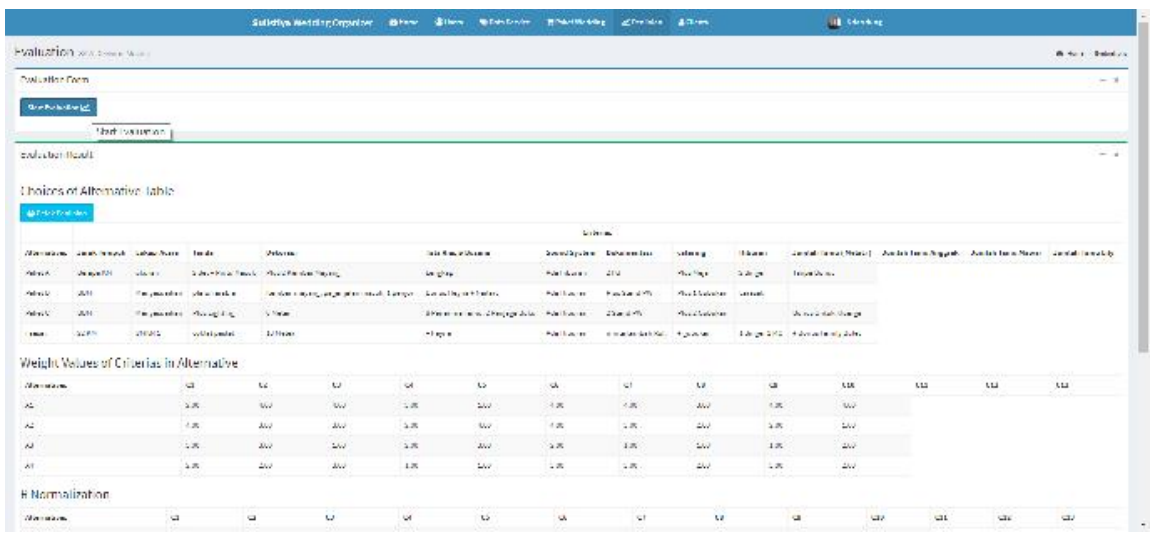

Gambar 4.7 Halaman Penilaian

\subsubsection{Implementasi Antarmuka Data Client}

Halaman data client merupakan halaman data client yang ditambahkan admin. Implementasi antarmuka web data kamar kost ditunjukkan pada gambar dibawah ini

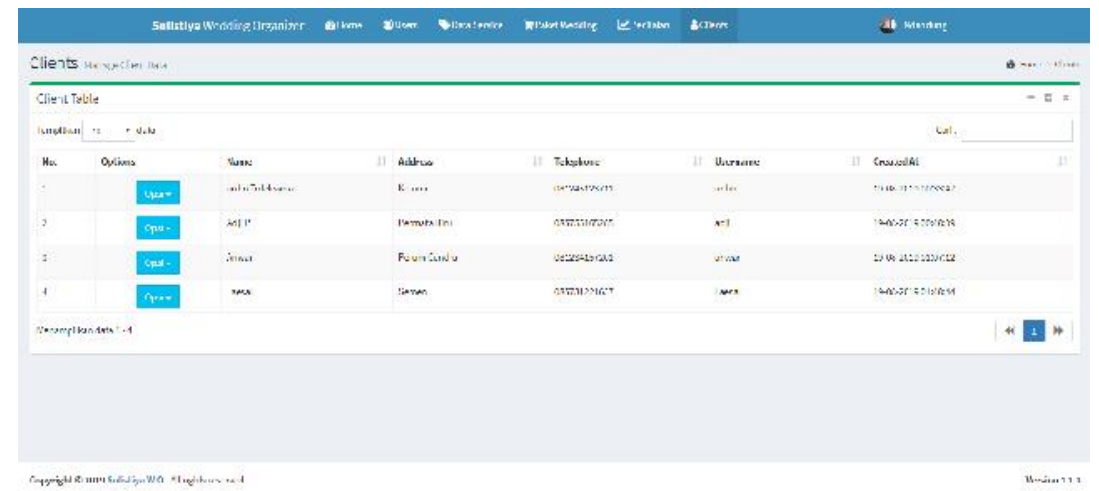

Gambar 4.8 Halaman Data Client 


\subsubsection{Implementasi Antarmuka Web Pada Client}

Halaman home pada client merupakan halaman yang diberikan untuk melakukan order. Halaman client dapat diakses oleh client setelah mendapatkan password dari admin. Pembahasan home pada client ditunjukkan pada gambar dibawah 4.9 :

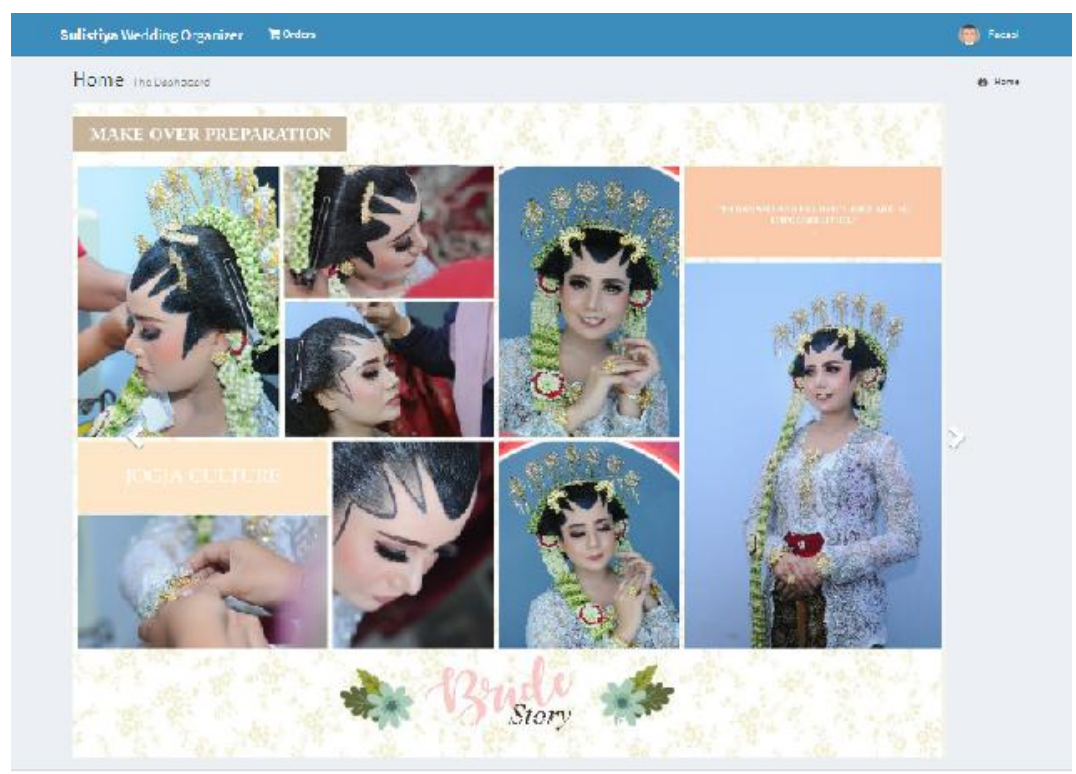

Gambar 4.9 Halaman Web Klient

\subsubsection{Implementasi Antarmuka Order}

Halaman order merupakan langkah untuk menambahkan order dari hasil penilaian sebelumnya pada sistem. Pada halaman ini client juga dapat merubah detail order. Pembahasan home pada client ditunjukkan pada gambar dibawah ini

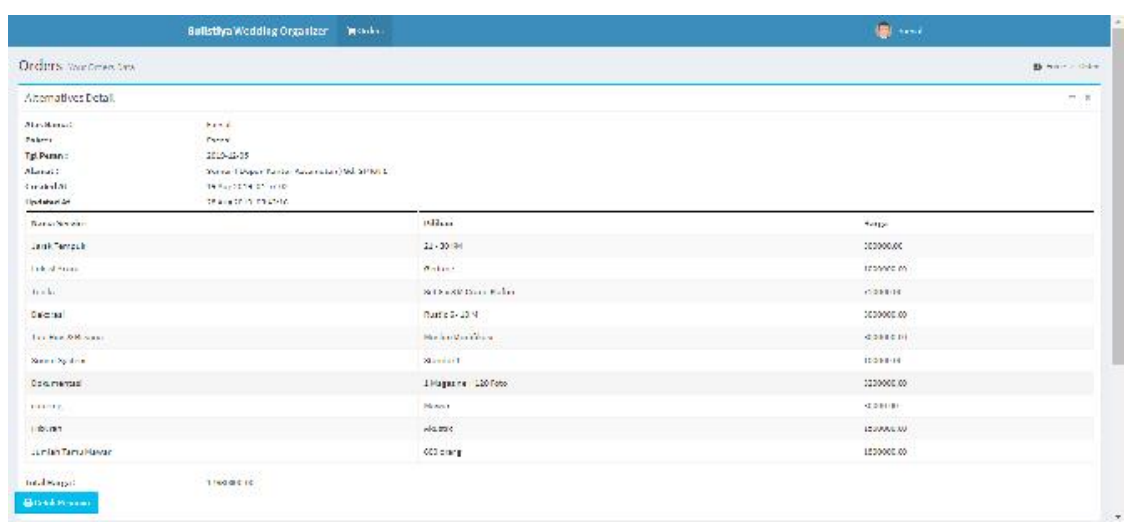

Gambar 4.10 Halaman Order

\section{Kesimpulan Dan Saran}

\subsection{Kesimpulan}

Setelah melakukan keseluruhan proses penelitian dan pembuatan program ini, peneliti mangambil kesimpulan bawasanya metode Simple Additive Weighting dapat digunakan sebagai alternatif terbaik dalam perhitungan sistem pendukung keputusan dalam hal ini pemilihan paket pernikahan sesuai keinginan pelanggan. Dari sistem yang sudah dibuat juga mempermudah pengguna dalam hal ini Sulistiya Wedding Organizer untuk melayani pelanggan dan juga mengolah jasanya. 


\subsection{Saran}

Pada penelitian ini, masih diperlukan adanya perbaikan pada sistem aplikasi tersebut karena masih terdapat sejumlah kekurangan di dalamnya. Untuk itu, penulis perlu memberikan saran untuk pengembangan dan peneliti yang akan datang yaitu:

1. Melakukan analisis lebih lanjut terhadap penentuan batasan dari metode SAW.

2. Mengembangkan program ini secara online, sehingga dapat mengambil hasil keputusan dimanapun berada dan dapat digu- nakan untuk pengelola Wedding Organizer yang lain.

\section{References}

[1] Fitriani. (2012). Sistem Pendukung Keputusan Pemilihan Rumah Sakit Bersalin Studi Kasus Pangkal Pinang. Skripsi Mikroskil. Medan.

[2] Komputer, Wahana. 2010.Panduan Belajar MySQL Database Server. MediakitaJakarta Selatan.

[3] Kusumadewi, S., Hartati, S., Harjoko, A., Wardoyo, R. (2006). Fuzzy Multi Atribute Decision Making Fuzzy MADM. Yogyakarta: Graha Ilmu

[4] Nanda, A. (2015, April 1). Pengertian Website. Dipetik Desember 18, 2017, dari http://ehnanda.blogspot.co.id: http://ehnanda.blogspot.co.id/2015/01/pengertian-website.html

[5] Nugroho, A. (2013, Januari 14). Data Flow Diagram. Dipetik Desember 18, 2012, dari http://informatika.web.id: http://informatika.web.id/category/data-flow-diagram/

[6] Sugiono. (2005). Memahami Penelitian Kualitatif. Bandung : CV. Alfabeta

[7] Sutanta. (2014). Pengertian Entity Relationship Diagram (ERD) Menurut Sutanta. Dipetik Desember 18, 2017.

[8] S. W. Mudjanarko, S. Winardi, and A. D. Limantara, "Pemanfaatan internet of things (iot) sebagai solusi manejemen transportasi kendaraan sepeda motor," Pros. Semin. Nas. Apl. Teknol. Prasarana Wil. X, no. August, 2017.

[9] A. D. Triono et al., "Utilization of Pedestrian Movement on the Sidewalk as a Source of Electric Power for Lighting Using Piezoelectric Censors," in 2018 3rd IEEE International Conference on Intelligent Transportation Engineering, ICITE 2018, 2018.

[10] A. D. Limantara, L. D. Krisnawati, S. Winardi, and S. W. Mudjanarko, "Solusi Pengawasan Kebijakan Mengatasi Kemacetan Jalan dan Parkir Kota Berbasis Internet Cerdas," Semin. Nas. Teknol. dan Rekayasa Inf., no. November, pp. 1-6, 2017.

[11] A. D. Limantara, S. Winarto, and S. W. Mudjanarko, "Sistem Pakar Pemilihan Model Perbaikan Perkerasan Lentur berdasarkan Indeks Kondisi Perkerasan (Pci)," Semin. Nas. dan Teknol. Fak. Tek. Universtas Muhammadiyah Surakarta, no. November, pp. 1-2, 2017.

[12] A. D. Limantara, Y. Cahyo, S. Purnomo, and S. W. Mudjanarko, "Pemodelan Sistem Pelacakan LOT Parkir Kosong Berbasis Sensor Ultrasonic Dan Internet Of Things ( IOT ) Pada Lahan Parkir Diluar Jalan,” Semin. Nas. Sains dan Teknol., vol. 1, no. 2, pp. 1-10, 2017.

[13] A. Alimudin, A. Z. Falani, S. W. Mudjanarko, and A. D. Limantara, "Analisis Pengaruh Penerapan Perspektif Balanced Scorecard Terhadap Peningkatan Kinerja UMKM,” Ekonika J. Ekon. Univ. kadiri, vol. 4, no. 1, p. 1, 2019. 